\title{
Caracterização do perfil mineral em bovinos de corte em Cachoeira do Sul (região da Depressão Central do Rio Grande do Sul)*
}

\author{
STELLA DE FARIA VALLE
}

Félix H. Diaz González (Orientador - UFRGS)

Banca: Júlio O. J. Barcellos (UFRGS), Marcelo Cecim (UFSM), Sérgio C. Silva (UFRGS)

Os minerais são de extrema importância no metabolismo geral e no desempenho produtivo e reprodutivo dos animais a campo. Atualmente, no Rio Grande do Sul, há poucos relatos sobre o diagnóstico de deficiências de minerais através da análise de macro e microelementos em fluidos biológicos. As informações disponíveis limitam-se ao diagnóstico clínico de deficiências isoladas e à análise de elementos nas pastagens, que sugerem deficiências subclínicas de alguns elementos minerais. A região da Depressão Central é caracterizada pela produção extensiva em campo nativo com manejo precário da suplementação mineral. A incidência de baixos níveis de alguns elementos nas pastagens contribuiu para a escolha da região. Os objetivos do presente trabalho foram: (a) determinar o perfil mineral em quatro períodos importantes do ciclo produtivo de matrizes (monta, repasse de touros, final da gestação e início da lactação); (b) diagnosticar possíveis deficiências minerais em vacas de corte na região da Depressão Central mediante a dosagem dos seguintes indicadores no sangue: Pi, $\mathrm{Ca}, \mathrm{Cu}, \mathrm{Zn}$, glutation peroxidase (Se) e tiroxina (I). Na saliva foram dosados $\mathrm{Na}$ e K. (c) correlacionar os indicadores com os teores de minerais na pastagem nativa. Para isso, foram obtidas amostras de sangue e saliva em 4 propriedades no município de Cachoeira do Sul totalizando 112 animais (28 por período). O perfil indicou deficiência marginal de $\mathrm{P}$, $\mathrm{Na}$, I e $\mathrm{Se}$ em todos os períodos. As médias de $\mathrm{Cu}$ e $\mathrm{Zn}$ estiveram dentro das referências enquanto que os de $\mathrm{K}$ na saliva mista estiveram elevados. O Ca sérico apresentou-se diminuído, embora os teores nas pastagens estivessem elevados. Foi constatada baixa correlação entre os níveis de minerais no sangue/saliva e na pastagem de todos os elementos. Os períodos mais afetados foram o final da gestação e início da lactação indicando que essas categorias possuem maior necessidade fisiológica.

Descritores: perfil mineral, saliva, glutation peroxidase, tiroxina, vacas de corte, Rio Grande do Sul.

\footnotetext{
* Dissertação de Mestrado n. 334 (Especialidade: Patologia Animal). 92f. Programa de Pós-Graduação em Ciências Veterinárias, Faculdade de Veterinária de Porto Alegre - UFRGS. CORRESPONDÊNCIA: S.F. Valle [e-mail: stellve@terra.com.br].
} 


\title{
Mineral profile characterization in beef cattle from Southern Brazil**
}

\author{
STELLA DE FARIA VALLE
}

Félix H. Diaz González (Adviser - UfRGS)

Committee: Júlio O. J. Barcellos (UFRGS), Marcelo Cecim (UFSM), Sérgio C. Silva (UFRGS)

Minerals play an important role in the metabolism and in the production and reproductive performance of animal raised on extensive grassland. Presently, in the state of Rio Grande do Sul (Southern Brazil) there is a lack of information on macro and micro elements mineral deficiency troughout the analysis of biological fluids. Information available in this field reports only individual cases of mineral deficiency and analysis of elements on pastures. The level of mineral found on pasture suggests the presence of non-clinical mineral deficiency of some elements in either some seasons of the year or on the different animal categories of the State herds. The Central Valley Region, the third most important social and economically cattle industry of the State, is characterised by extensive production on natural pasture, with quite poor mineral supplementation. The low mineral levels found on pastures in this area, detected by previous works, suggest further investigation. The main aims of this work were: (a) to detect possible mineral deficiency in beef cows by determining $\mathrm{Pi}, \mathrm{Ca}, \mathrm{Cu}, \mathrm{Zn}, \mathrm{Se}$ (gluthathion peroxidase) and $\mathrm{I}\left(\mathrm{T}_{4}\right)$ in blood and $\mathrm{Na}$ and $\mathrm{K}$ in saliva; (b) to check the possible relationships with the mineral level on pasture; (c) to detect the mineral profile on four different periods of the productive circle (IA, clean up bulls, end of gestation period and beginning of lactation). A total of seven blood and saliva samples were collected from each of four herds of Cachoeira do Sul town on four different periods. The results showed marginal deficiencies of $\mathrm{Pi}, \mathrm{Na}, \mathrm{I}$ and $\mathrm{Se}$ in all periods of the year. Mean values of $\mathrm{Cu}$ and $\mathrm{Zn}$ were among normal levels but the $\mathrm{K}$ level was above the reference level. The Ca serum level was always bellow normal and could be related to the low protein ingestion and high Mg pasture level. Finally, only a low relationship was found between mineral level on blood/saliva and pasture levels. Most critical periods were end of gestation and beginning of lactation, suggesting a relationship with the physiological need of those periods.

Key words: mineral profile, saliva, gluthation peroxidase, tiroxine, beef cows, Southern Brazil.

\footnotetext{
** Master's Thesis no. 334 (Field: Veterinary Pathology). 92p. Postgraduate Program in Veterinary Sciences, Faculdade de Veterinária de Porto Alegre, Universidade Federal do Rio Grande do Sul (UFRGS) - Brazil. CORRESPONDENCE: S.F. Valle [e-mail: stellve@terra.com.br].
} 